\title{
The Charm of Piano Music in the Movie "A Song to Remember"
}

\author{
Chen Liang \\ Xi’an Conservatory of Music, Shanxi Xi'an, 710061
}

Keywords: "A Song to Remember"; piano music; charm display

\begin{abstract}
A Song to Remember" is a biography of a film with Chopin and his works as the main line. The main idea that he wants to express in this movie is very obvious. The piano music also runs through the whole process of the film. It has important significance for the rendering of the story atmosphere, the promotion of the storyline and the expression of the theme. The film also effectively makes the audience feel the charm of piano music in "A Song to Remember". This paper analyzes the charm of piano music in "A Song to Remember" and gives an in-depth understanding of the piano music in its film.
\end{abstract}

\section{Introduction}

For a film, music has an important role to play in order to achieve effective theme expression. Good music collocation is also a necessary way to promote the atmosphere of the film and deepen the mind. In the movie "A Song to Remember", this one Chopin's main character biography film uses a lot of Chopin's piano music to perform the theme, which not only effectively promotes the development of the story, but also shows the musical talent and personality charm of Chopin. How to show the charm of piano music in the "A Song to Remember" is also the main research content of this paper.

\section{A review of the movie "A Song to Remember"}

The film "A Song to Remember" was filmed in 1945. It mainly described the short-lived life of the great romantic pianist Chopin. At that time, Poland was under the control of foreigners, and was oppressed by Tsarist Russia. The piano music has already had the characteristics of romanticism. After the failure of the Warsaw Uprising, Chopin fled to the artistic capital of Paris, and in this period of Chopin's works, he also fully expressed his inner sadness. The lack of passion and strong patriotism, in this film, the ingenious use of gorgeous sets and rich colors and various montage methods to display, has also become a colorful Rhapsody, in 1945 in China to release a huge repercussions.

The film tells the story: In 1821, Poland was invaded and ravaged by Russia. In the environment of heavy hooves, Chopin was only eleven years old, but he already had excellent piano playing skills and level of composition. After entering the youth, he actively engaged in the revolutionary movement, and also collided with the tsar in a salon concert, which caused him to murder, and then fled to Paris. In Paris, when family members were persecuted and needed to open a concert to raise money, Chopin decided to use the tour to fundraise to support the frontline bloody warriors, so that he ended his life with fatigue. Chopin fully explained his feelings about patriotism with his life. The film "A Song to Remember" is also based on music as a skeleton, thus unfolding the narrative of Chopin's legendary life, and then shaping the music poet in music ${ }^{[1]}$.

\section{The charm of piano music in the movie "A Song to Remember"}

\subsection{The emotional experience in the performance of "Polonaise Fantasie in A-flat Major"}

The piano works created by Chopin are mainly influenced by the Polish real society. This Polish dance music has a profound temperament of the Polish region. At the same time, Polish dance music is Chopin's favorite work. It also lasted for nearly 30 years for Polish dance music creation. 
This also infiltrated his love for the nation and the motherland, and also showed great worries to the motherland under the disaster. The theme of his work is closely related to the patriotic plot and national liberation. In the film "A Song to Remember", Chopin has left Poland, and his heart is still very concerned about the motherland and the people. This is also the expression of Chopin's emotion in this film. The overall tone of this song is very lively and tense, which also portrays the brave performance of Polish soldiers in the face of war, and then its tone shifts to a fierce and solemn atmosphere, which also shows the fearless and resistant spirit of the Polish people facing the aggressors, and then the music enters the excitement, just like in mercedes killing warriors on the battlefield, thus expressing a scene of war through music, and then entering a soothing music, giving people a short-term respite, the final ending has the same tone as the beginning, echoing the beginning. This is also a true portrayal of Chopin's mood ${ }^{[2]}$.

\subsection{Emotional experience in the performance of "Revolutionary Etudes"}

The piano piece of "Revolutionary Etude" was created by Chopin in September of 1831. On the way to France, he knew that the Warsaw Uprising was the result of defeat. Then he wrote the piano piece impromptuly. The theme of this song is the expression of the revolutionary spirit. This is also the origin of its name. This song has appeared many times in the film. For the first time, when Chopin played on the Duke, the Duke was respectful and let the invaders go to the seat, which triggered Chopin's patriotic sentiment, the music began to sound, and through the excitement of music, it showed the anger of Chopin. When Chopin went away, it also set off the national ethics of Chopin $^{[3]}$. When the audience sees this part, they can feel Chopin's inner feelings. The film inserts this piano piece in this position, which can effectively express Chopin's patriotic feelings and promote the film's more expressive and appealing power. In addition, this piano piece has always appeared with the changes of its friends. This piano has appeared in the story of the revolutionary friends knocking on the door, the partners suggesting that they leave Poland, the revolutionary partners are arrested and the revolutionaries are suppressed. The frequent appearance of this piano piece, also played a positive role in the development of the plot. This arrangement of music and film plots is not only a rendering atmosphere, but also allows the audience to truly feel the emotions of Chopin's heart and give the audience a more realistic and rich experience.

\subsection{The emotional experience in the performance of "Puppy Waltz"}

This piano piece was created by Chopin in 1846, which was also written in the final stage of his life. The inspiration for this is from a puppy, a puppy with his girlfriend, who runs around happily every day. In this manor-style life, Chopin wrote the piano music. It was played for only one minute, and its speed was faster, and the tone was also very pleasant, showing the indifference that Chopin had in a harmonious life. In the film "A Song to Remember", "Puppy Waltz" was played when Juvenile Chopin appeared. It is very useful to use this song at the beginning of the film. Although it can't directly express the theme, it does not. Indirectly, it shows Chopin's spirituality to music art. This musical talent is possessed from childhood, and it has a certain premise to become a piano poet in the future development. At the same time, this song also hinted at the close relationship between Chopin and George Sang. Therefore, this song also has a playful role in the film, implicitly showing the follow-up development of the film. At the same time, the tone of this relationship continues until the end of the film, effectively help the audience to carry out emotional brewing and understanding ${ }^{[4]}$.

\subsection{Emotional experience in the performance of " Serenade in E flat major "}

The "Nocturne" is mainly expressed in a soft bass form. The bass is in a wavy state. The nocturne is also influenced by Feld's nocturne. The sweet and warmth is the main theme, so that his piano is called for the classics, this song is also played by many musicians. His song was created in 1830 and is Chopin's early work. The tone of his works is soothing and lyrical, with a poetic picture. In the film "A Song to Remember", this song appeared in Chopin and George Sang in the plot of sweet love. With George Sang, accompanied by Chopin, he concentrated on the creation of music. The two spent the most comfortable period in the quiet islands. This song also appeared at this time. 
The song is accompanied by a gentle pop-up of the melodious piano, giving the audience a happy atmosphere, clearly feeling the love of Chopin as a poetry by the piano poet. The emotional experience conveyed by the film is not only conveyed through its picture, but also combined. Music gives a sense of mutual enjoyment of sight and hearing.

\section{Conclusion}

In summary, through the film "A Song to Remember", the film successfully shows a great musician with soul and thought. In this film, Chopin's life is combined with the love of music. Through the effective combination of film and piano music, it shows the great accomplishment of a great musician to music, and the incomparable love and love for music. The noble emotions have the pursuit of advocacy, but also show the patriotism of Chopin.

\section{References}

[1] Chen Yufeng. Interpretation of the Aesthetic Features of Chopin's Piano Works in the Unforgettable Film[J]. Anhui Literature (2nd Half), 2016(10):80-81.

[2] Wang Xiangru. The Application Research of Piano Art in the Film "A Song to Remember"[J]. Short Stories (original edition), 2015(15): 101-102.

[3] Bao Qifeng, Zhu Pingyu. Appreciation of Piano Music in the Film "A Song to Remember" [J]. Film and Literature, 2014, No.598 (1):156-157.

[4] Zhang Yu, Gao Ang. The Emotional Experience of Piano Music in "A Song to Remember"[J]. Movie Literature, 2010, No.521 (20): 139-140. 